Сергеј Мацура

Универзитет у Београду

Филолошки факултет

sergej.macura@fil.bg.ac.rs

https://doi.org/10.18485/ai_diskurs_pobede.2019.ch11

821.131.1.09-31 Еко У.

\title{
РЕКОНСТРУКЦИЈА ИСТОРИЈСКИХ ДЕШАВАҢА КРОЗ ДЈЕЧЈУ ЛЕКТИРУ: ТАЈАНСТВЕНИ ПЛАМЕН КРАЉИЦЕ ЛОАНЕ
}

Главни јунак романа Умберта Ека, Ђамбатиста Бодони, послије можданог удара присјећа се сопственог животног пута и креће од најранијих искустава читања не би ли надвладао амнезију. Јавно је у школи упијао идеологију фашизма без знања о темељима тог система, а сада истражује какав је став о фашизму имао у дјетињству. Бодони педесет година касније схвата дубину трауматичности и репресије своје породице, а посебно дједа, чији се отпор и освета угњетавању фашиста могу сматрати како породичним тако и генерацијским искуством једне нације. Затечени текст се састоји од читанки, пропагандног материјала и огромног броја стрипова.

Кључне ријечи: реконструкција, фашизам, тоталитаризам, стрипови, пропаганда, семантичко памћење, аутобиографско памћење, Умберто Еко, Бенито Мусолини.

Године 2004. објављен је и на српски преведен роман Умберта Ека Тајансиивени йламен краљище Лоане (La fiamma misteriosa della regina Loana), који као и остали романи овог писца, почива на топосу затеченог текста чији настанак треба да се у току дијегезе рекон- 
струише. Ђамбатиста Бодони, антикварни књижар из Милана, доживљава мождани удар априла 1991. са 59 година живота, што само наоко симулира животни пут емпиријског аутора, јер је Еко рођен јануара 1932. године, а фикционални Ђамбатиста звани Јамбо претходи му за око мјесец дана. Сада лик у болници и током опоравка на дједовом сеоском имању покушава да склопи комадиће сопствене историје, а пошто је веома образован, често се испомаже цитатима многих књижевних дјела, што може бити и његово лично, али исто тако и колективно памћење - са Еком се увијек мора рачунати на урањање и ликова и читалаца у такозвану „енциклопедију свијета“.

Од самог почетка приповједне реконструкције, главни лик показује одлично памћење општеисторијских и других приручничких података, као што је случај пацијента са ретроградном амнезијом из 1926. године, који је завршио у лудници у Колењу, али се Ђамбатиста не сјећа се гдје се родио. Доктор му укратко објашњава врсте памћења: имплицитно, које омогућава извођење научених радњи (прање зуба, везивање кравате и слично), и експлицитно, при чему знамо да се сјећамо извора, а оно само се дијели на семантичко/ јавно (ласта је птица, Наполеон је умро) и епизодно/аутобиографско, када на примјер дјеца истог пса сматрају различитим ентитетима и треба им времена да науче да је у питању идентична животиња (Еко 2004: 16-17). Епизодно памћење успоставља везу између онога што смо сада и онога што смо били, и на неки начин је аналогно Штанцловој разлици између приповједног Ја и доживљајног Ја унутар псеудоаутобиографских наративних текстова. Будући велики поштовалац књига и штампе, Јамбо располаже огромним бројем цитата из разних дјела и многих епоха, који му парадоксално омо- 
гућавају да се приручно снађе - на љекарово питање да ли жели да му се донесе чај одговара: „Како вам gраїо“ (Еко 2004: 18, курзив у оригиналу). Врло чврст општеобразовни оквир налази се у ироничном раскораку са Јамбовим потпуним незнањем о својој животној историји, запретеној у неком још неактивираном дијелу мозга. Супруга Паола, по струци психолог, помаже му да се сјети дајући му информације из тридесетак година дуге брачне историје, али по археолошким остацима

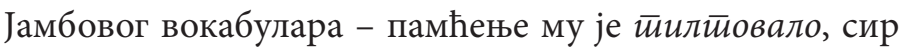
сйракино који се тако зове само у Пијемонту - доктор одлучује да га отпусти кући, пошто ће му стимулуси из властитог окружења помоћи више него стандардизовани неуролошки тестови.

Слика магле која се јавља у Јамбовој глави и у стотинама цитата које је из књижевности прикупио метафора је његове амнезије, али и путоказ ка темељима сјећања које, како најдубљи осјети наговјештавају, лежи у Солари, варошици његовог рођења и дјетињства. Да сусрет са истином о самом себи буде још напетији, Паола приповиједа Јамбу о томе да за све деценије брака никад није радо одлазио у Солару, остајао би по неколико дана, и никада није залазио у „светилишта“, своју некадашњу собу, собе родитеља, дједа и бабе, као ни на таване (Еко 2004: 40). Послије неколико седмица опоравка у Милану, одлучује да проведе неко вријеме на селу како би скинуо копрену заборава из свијести, а на то га првенствено подстичу фрагменти стрипова из предратног Микијевоі алманаха и сличне дјечје лектире. Друго важно питање на које треба да одговори гласи: каква је политичка убјеђења гајио читавог живота и колико се његова идеолошка позиција мијењала у разним епохама? Овај чланак се бави контекстуализацијом Јамбовог дјетињег и школског искуства 
кроз несигурну ретроактивну херменеутику сопства којој приступа као пионирски истраживач самог себе, а испомаже се историјским доказима који омогућавају формирање прецизнијег става читаоца према јунаковој индивидуалној историји у контексту врло бурне епохе, пошто је Јамбо рођен и до дванаесте године школован у окриљу фашистичке Италије под тврдом влашћу Бенита Мусолинија (итал. Benito Mussolini). На метанивоу читалачке рецепције, сагледавање јунаковог самосазнања може се сматрати и студијом случаја о образовању идентитета и далекосежним утицајима школске лектире, кроз коју се често провлачи злокобна идеологија а да то њени малени примаоци упију без рационалног отклона.

Послије Првог свјетског рата Италија се налазила у дубокој политичкој кризи, која је отворила врата многим несређеним и екстремистичким покретима да покушају да преовладају на државној сцени - некадашњим војницима, студентима, ратним хушкачима и новооснованој групи по имену фашисти (итал. fasci di combattimento или борбене јединице). Испрва су обећавали читав спектар повољности са разних идеолошких становишта: антиклерикализма, национализма, права жена, радника и борбе против ратних профитера, а потом су прешли на агресивно гушење социјалистичког и католичког дјеловања по цијелој Италији, и послије три године стања налик на грађански рат, Бенито Мусолини је формирао Националну фашистичку партију (итал. Partito nazionale fascista), која је преузела већину чланства дотадашњих синдиката. Када се октобра 1922. године десетине хиљада фашиста запутило на Рим и тамо заузело саобраћајнице и администрацију, краљ Виторио Емануеле III је покушао да Мусолинија обузда уставним средствима, па му је понудио мјесто 
предсједника владе (Marino et al. 2019: par. 1-4). У задатку учвршћивања режима на наредних сто година, Мусолини је морао за себе придобити симпатије и срца омладине; антиклерикални Дуче је увео низ мањих реформи које су премостиле јаз између државе и цркве, као на примјер, враћање распећа у учионице и суднице, поново је увео катихезу у основне школе и акредитовао Католички универзитет у Милану. Министар просвјете Ђовани Ђентиле (итал. Giovanni Gentile), заслужан за низ законских аката и измјену школског система 1922/1923. године, био је филозоф идеализма, који је вјерску наставу сматрао само једним степеном у развоју више критичке мисли: „Касније, када дијете порасте и сазре духом, биће у стању да самостално напусти дјетињасти појам религије који је учио у основној школи и превлада га сопственом мишљу“" (Gentile нав. према Wolff 1980: 6). Црква и фашистички режим су провели неколико година у пажљивом преиспитивању крхког детанта до око 1928. године, а тада је почела нова фаза сукоба. Под будним оком папе Пија XI, аутономна организација Католичка акција израсла је у друштвену силу од које је владајућа партија зазирала, због великог броја чланова и примјетног црквеног утицаја на лаике који су се налазили у локалним одборима. Када је марта 1928. понтиф одржао говор пред римским одбором Католичке акције у коме је критиковао план фашистичке владе да монополизује физичко и духовно образовање омладине, влада је забранила дјеловање Католичким младим извиђачима и пустила силеџије да нападају јединице Италијанске католичке универзитетске федерације (FUCI), главне конкуренте у придобијању симпатија студената. Иако је Латерански уговор из 1929. године формално донио помирење државе и цркве и проширење вјерске наставе на средње школе, Дуче је 
свега неколико мјесеци касније категорички одбацио жеље Ватикана да уведе вјеронауку и на универзитете, и на тај начин изазвао дуготрајну полемику са папом, који се успротивио Мусолинијевом науму да у дјецу усади осјећај за освајање, јер је то у директној супротности са католичком доктрином (Wolff 1980: 10-12).

Децембра 1929. године папа је издао енциклику Divini illius Magistri, усмјерену на поновно успостављање црквене надлежности над образовањем, пошто се црква налази ван државне власти и има инхерентну улогу у том процесу; поред тога, напао је и омладинску организацију Балиле због националистичког индоктринирања и времена које би се умјесто на ратне припреме могло утрошити на духовне и пацифистичке садржаје. У затишју пред буру, усвојен је закон којим се уводи вјерска настава у средње школе, а отворени сукоб је отпочео 1931. године; фашисти су физички напали многе припаднике FUCI и за два мјесеца успјели да их угасе, под изговором да су се још осјећали утицаји некадашњих народњака у организацији (у ствари је код фашиста превладала жеља да образовање ставе под апсолутну контролу, без уплива „стране државе“). Пошто ни држави ни Ватикану није ишло у прилог да се институционални рат настави, дошло је до компромиса већ септембра исте године - Католичка акција постала је децентрализована и није учествовала у политичким и спортским активностима, а садржаја са величањем фашизма и католичанства у школским уџбеницима било је подједнако. Ограничене тензије потрајале су до 1938. године, када је Мусолини коначно прихватио Хитлерову расну теорију и тиме нанио додатну увреду свештеницима романског поријекла, а Католичка црква није износила теже замјерке на нови Закон о образовању (усвојен 1939. године са утицајима лијевог фаши- 
стичког крила). Министар Ђузепе Ботаи (ital. Giuseppe Bottai) више је смјерао да из школе избрише утицаје буржоаског и елитистичког друштва него да цркви онемогући било какав приступ образовању. До тада је Ватикан скоро двије деценије капиларно био присутан у италијанском школству, које фашисти нису успјели да тотализирају као што су то учинили нацисти у Њемачкој (Wolff 1980: 20-22).

Реконструкцију животне историје Јамбо почиње прегледом свих хаотично расутих археолошких података који се на тавану налазе: модних часописа, кутија цигарета, фризерских календара, авантуристичких романа из ХИХ вијека и слично. Чак и надимак му је дошао из лектире за узраст од 5 до 7 година: „Преда мном су се указале Чуйеркове йустиоловине извесног Јамба. [...] Ту се дакле родио Јамбо, желео сам да будем као он“ (Еко 2004: 149). Прекопавајући ту базу података, јунак се суочава са све неизвјеснијим уласком у сопствени развојни пут, управо због огромне масе знакова који ступају један са другим у бескрајну семиозу и отварају превелик спектар могућности за постављање погрешних хипотеза.

Први путоказ који исијава и семантичко и аутобиографско памћење, као и националну обојеност, Јамбо види у комплету стрипова о Буфалу Билу: „Приметио сам да на насловној страни пише Буфало Бил - херој üрерије, док је на првој унутрашњој страни писало и Бубало Бил - ийалијански херој йрерије“ (Еко 2004: 156-157). За издања из 1942. године та измјена није била чудна (колико год у свијету авантуристичког издаваштва била апсурдна), пошто је након објаве рата Сједињеним Државама на снагу ступила одлука да хероји морају бити искључиво Италијани. Наде да је то можда једина диктаторска индоктринација урушавају 
се одмах сутрадан, по проналаску књиге Ийалијанска gјеца у свијетиу Пине Баларио:

Сатима сам се пржио на сунцу све док оно није опловило прочеље куће, па је температура постала подношљивија. Али како бих иначе могао да осетим андалузијско сунце које сам замишљао као дечак, премда се радња одигравала у Барселони. Група младих Италијана, која је са породицом емигрирала у Шпанију, улеће у вихор антирепубликанске револуције генералисимуса Франка, само што су у мојој причи узурпатори били републикански добровољци, крвожедне пијанице. Младим Италијанима се поново јавља фашистички понос и у црним кошуљама неустрашиво јуре Барселоном у којој све више пламти буна. Успевају да спасу заставу са Дома фашиста који су републиканци затворили, а одважни јунак успева чак и да врати свог оца, испичутуру и социјалисту, на прави, Дучеов пут. (Еко 2004: 158-159)

И садашње и ондашње Ја на аналоган начин се отискују у авантуру читања, урањајући у већ припремљену идеолошку матрицу, коју стари Јамбо захваљујући семантичком памћењу разумије кроз превредновани закључак о истинитости оваквих тријумфалних пројекција (да не помињемо и најновија схватања појединих екстремистичких група у Италији које ходочасте на Мусолинијев гроб). Вођен бујицом података и незнањем о осјећају који су му будили појмови херојства и части као основна оруђа идеолошких епистема, Бодони није сигуран како је разликовао основне категорије добра и зла: „Ко је био мој херој? Холмс који је читао писма испред камина благо запањен решењем којем је давао само седам посто или Сандокан, који је бесно кидао своје груди изговарајући име вољене Маријане?“ (Еко 2004: 168) Неодређеност сазнања да ли се у дјетињству дивио фашистичким пјесмама или је слу- 
шао и стандардну дјечју музику ствара му утисак да је младом Јамбу у души морао владати расцјеп: „...у души дечака, кога засипају порукама о величанствености нације, док он машта о лондонским маглама“ (Еко 2004: 185). Послије сат времена слушања фашистичких корачница, више није у стању да нормално мисли од све пропаганде о јуришима, храбрим погибијама, оданости Дучеу, Риму и новом царству, као и поновном заузимању Нице, Савоје, Абисиније, Корзике, Малте, Туниса и других крајева из империјалне маште фашистичког руководства. Империјално ширење Италије била је Мусолинијева дугогодишња опсесија, а Јулије Цезар његов омиљени Римљанин, виши по постигнућима и од Августа, док су у новом појму romanità једна поред друге текле струје уздизања велике прошлости и изградње новог друштва на принципима футуристичко-технократског модернизма (Nelis 2007: 407). Тада одлучује да неизоставно пронађе школске уџбенике, који би својом хронологијом и каталогизацијом лектире из дотичних година могли помоћи у одгонетању коју музику је слушао док је читао разноврсне књиге и како је то емотивно спајао у вријеме тоталитарног државног апарата.

Јамбо проналази педантно спаковане књиге и свеске, и приступа истраживању попут историчара који је ушао у богат архив, док му амнезија омогућава висок степен објективности, а при читању школске грађе паралелно проучава и периодику из тих година, на тај начин стварајући метаниво контекста. На маргинама новина његов дјед је брижљиво уписивао и податке које је слала друга страна, као на примјер Радио Лондон, па их је укрштао са италијанским и стицао прецизнију слику о ратним збивањима. У режимској пропаганди налазило се сувише дискурса херојства и побједе да би искусни читалац у то повјеровао, а то је Јамбу постало јасно 
тек послије педесет година - само су се у кратким, назовимо их протоколарним вијестима, очитовале непобитне математичке чињенице, а и она каткад скривене. Дјед је на практичан начин унуку дао наук како се чита између редака, и да се детаљне информације у италијанској штампи углавном односе на њихове тријумфе; пошто сваки систем знакова мора имати барем два члана да би био систем, тако је функционисао и овај: опширне мапе или описи војних кретања значили су потенцијално италијанско напредовање, а њихово одсуство подразумијевало је италијанске поразе, који су или умањивани или прећуткивани у тоталитарној држави.

Еков јунак сада приступа поновном читању аутентичног уџбеника за први разред основне школе, који је приредила Марија Цанети (Maria Zanetti: Il libro della prima classe, Verona, 1936), и тако стаје са обе стране историје: своје личне, која може бити искривљена разним „маглама“ из деценија читања тог симболичког топоса, и националне, пошто се и у историографским изворима из Другог свјетског рата потврђује аутентичност овог италијанског буквара. Упоредба појаве агресивне државне пропаганде у италијанском, њемачком, француском, енглеском, холандском и америчком уџбенику дала је забрињавајуће податке: националистичких симбола је било на 45\% страница текста, двапут више него у њемачком и француском уџбенику заједно (друга три нису садржала ниједан), а од укупног броја страница са сликама, на 35\% су се јављале заставе, вође и слике војних јединица (опет испред свих такмаца на списку). Удружења омладинаца као Балиле била су у индоктринацији ефикаснија него школе (Abbott 1943: 284), па не чуди што Јамбо проналази илустрације са децидно милитантним садржајима у првом школском буквару: „Данас је 24. мај. Гуљелмо облачи нову белу 
униформу, то је униформа Синова Вучице. 'Тата, и ја сам Дучеов мали војник, зар не? Постаћу Балила, заставицу носићу, карабин имаћу, фашистички борац бићу““ (Еко 2004: 198). При сваком читању архивских текстова приморава себе да се запита да ли га је хватало усхићење овим пројекцијама или је то само учио напамет да оствари владин план и програм, који су ревносно спроводили упућени наставници. Све енциклопедије и приручници из времена послије 1945. године слажу се у оцјени штетности фашизма, и то Јамбо не доводи у питање, али још није у стању да схвати како се формирала његова најранија етичка позиција, а с њом и каснији погледи на политички живот (то што му Паола каже да је демократа и пацифиста опет не извире из његове потраге за аутентичним идентитетом). У читанци за четврти разред помињу се походи у источну Африку и сомалски легионари, „ти урођеници којима смо донели цивилизацију“ (Еко 2004: 203), иако је у тренутку када је то у школи учио Сомалија била под енглеском контролом. У читанци за пети разред садржаји пропаганде се разгранавају и заоштравају, па сазнајемо да је до тада у школске књиге ушао и антисемитизам, поред дуже присутног национализма и милитаризма: „тај гнусни јеврејски сој, који се подло увукао у аријевске редове [...] и у нордијским народима посејао зло семе ћифтинства и помаме за зарадом“ (Еко 2004: 203).

Јамбо се сада у часопису Оgбрана расе, који је почео са излажењем 1938. године, суочава са правом лавином бинарне пропаганде на политичким, финансијским и другим основима, која све непријатеље приказује као подљуде, дегенерике, полумајмуне и наказе; Кинези су мрски и генетски неподобни, али Јапанци се оцјењују повољно; Енглези су перверзни алкохоличари, новине Times у огледалу зову ce Semit, а Јевреји располажу чита- 
вом збирком кукастих носева и меснатих усана са искеженим зубима. Иронично, Дантеов нос се не описује погрдно, него га стављају у категорију „орловске расе“, а најупадљивија идеализација видљива је у цртежима младих Италијанки: бујних груди и благих облина, извајаних бокова у припијеним сукњама, на градској променади или на сеоском бициклу, просто су мамиле на љубав (Еко 2004: 204-206). Мусолини је лично пред Заступничким домом 1927. године истакао проблем „стерилних градова“, у којима су се драстично смањили и наталитет и проценат вјенчаног становништва, што је представљало велику опасност за амбиције Италије да постане империја - у суштини, наталитет је постао питање да ли ће Италија бити колонијална сила или колонизована земља. Поред ове неповољности, град је већ деценијама уназад у неким земљама Западне Европе био посматран као канцерогено ткиво које ће метастазирати, као губави организам који ће се распасти, а његово становништво је у расправама како либерала тако и социјалиста и националиста посматрано и као опасно и као угрожено (Horn 1991: 584).

На дан објаве рата, 10. јуна 1940. године, учитељ је ђацима издиктирао главне одломке из Дучеовог говора против свих „трулих западних демократија“ и у славу фашистичког морала: „Кад стекнемо пријатеља, онда ћемо корачати раме уз раме с њим до самог краја. Тако смо поступали, а и даље ћемо поступати према Немачкој, према њеном народу и њеним величанственим оружаним снагама“ (Еко 2004: 210). Иронија која не штеди милионе тадашњих ватрених присталица Дучеа постала је огледни час историје за десетине будућих генерација: Италија је љета 1943. збацила фашистичку владу, а септембра капитулирала, да би Њемачка одмах извршила инвазију на Апенине у циљу заустављања са- 
везничке армије. Како му навиру сјећања са нејасним референцама на то ко је непријатељ и како тријумфална војска само губи територије једну за другом, Јамбо жели да продре до дјетињег утиска који је могао бити само јединствен, упркос друштвеној схизофренији; утом проналази изворни документ из петог разреда основне школе, Године ХХ Фашистичке Ере (децембра 1942. године), састав на тему дјечака који морају чувати херојску културу Италије цијелог живота. Неколико одломака биће довољно да покажу степен индоктринације италијанских школараца:

Гле, прашњавом улицом креће се колона дечака. То су Балиле што поносито и одважно ступају, ... покоравају се одсечним командама својих предводника. Кад наврше двадесет лета, ти дечаци ће одложити пера и латиће се пушке да бране Италију од насртљивих непријатеља. ... Да! Бићу војник, борићу се, ако треба, даћу и свој живот за Италију, за њену нову, херојску, свету културу која ће донети благостање целом свету, јер божја је воља да таква култура процвета баш у Италији. (Еко 2004: 221-222)

Нови састав, написан девет мјесеци послије овог, био је цинична надреалистичка пародија буржоаске породице која отмјено дочекује госте чоколадним бомбонама (готово сигуран знак да их у стварности тада није било) и посједује несаломиву стаклену чашу; Јамбо је измислио причу у којој поносно представља гостима могућности чаше, најављује да ће је бацити на под без оштећења, али се она разбије у парампарчад, а он бризне у плач. Очито се радило о симболичком опису пораза на свим фронтовима, политичком, војном и друштвеном, али се у међувремену десило још нешто непознато што је малом Јамбу дало толико храбрости 
да се грађански освијести. Као прави детектив (и помало налик на избрушено логичног оца Вилијама из Имена руже), проналази тајну собу на тавану, у којој се крију нови докази његовог умног развоја током неколико година Другог свјетског рата.

Часопис Corriere dei piccoli нудио је напоредо измаштане свјетове и фашистичке подвиге за најмлађе читаоце, али и не тако цензурисане стрипове о мачку Феликсу и Биму и Буму; лист Vittorioso показивао је сличну уређивачку политику (фантастична земља 3ооландија смјењивала се са херојском прошлошћу Италије) па поред очитих ратних пораза, приказује храбре ратнике у афричким градовима који су до тада већ били у туђим рукама: „Наставили су мислећи да деца не знају ништа о мноштву кобних новости - а можда је тако и било“ (Еко 2004: 250).

Неколико годишта часописа Avventuroso пресудно је утицало на Јамбов укус, јер су му авантуре Флаша Гордона отвориле сасвим нов свијет; овај јунак се борио за слободу против деспота, а непријатељ Минг је служио Јамбу и као пројекција Мусолинија, диктатора који господари животом и смрћу својих поданика. Фантом господар џунгле живио је у слози са домороцима, од којих су неки показивали више хуманости него већина колонијалиста, а чаробњак Мандрак је слугу Лотара користио као тјелохранитеља, али га је третирао као пријатеља у пустоловинама. Иако су се по објави рата Америци ови стрипови претворили у наружене копије са фашистичким особинама, сјећање на Флаша Гордона остало је живо и у Јамбовом дјетињству и младости.

Једна од посљедњих појава умне магле везује се за ријеч из његове давне прошлости: „Валоне“, и јунак се у потрази налази као на рубу литице над неким понором у магли. Амалија, ћерка дједовог наполичара, објашња- 
ва Јамбу да је то стрмо брдо које води ка сусједном селу, на које су се несташни дјечаци верали. У вријеме послије капитулације, Јамбо је помогао члановима покрета отпора да спасу осам Козака тако што је водио групу низ опасно брдо усред магловите ноћи: „Укратко, то ће бити мој тренутак славе за праву, а не погрешну отаџбину“" (Еко 2004: 389).

Најважнија катарза у роману тиче се догађаја који се одвио још прије Јамбовог рођења, а сасвим је у складу са историјским контекстом раних двадесетих: његов дјед новинар имао је око 42 године када је у редакцију социјалистичког недјељника упала група фашиста, младих, разуларених и бахатих батинаша и натјерала га да послије премлаћивања попије бочицу рицинусовог уља, са предвидљивим и понижавајућим ефектима. Окануо се јавног дјеловања, а дио екскрета сачувао у другој бочици заједно са рицинусом. Пуних двадесет година у његову собу у Солари улазио би наполичар Мазулу и гледао бочицу, па дједа, и пружао длан па га обртао, уз завјереничку алузију: „Ако се обрне...” (Еко 2004: 286, курзив у оригиналу). У врло опасном контексту за такву комуникацију, обојица су једнодушно чекали да дође до политичких промјена, колико год се оне чиниле немогућим. Када је дошло до искрцавања Савезника на Сицилију, а јула 1943. године Мусолини развлашћен, и фашизму је дошао крај, јасан и основцу по најкрупнијем фонту на првим странама издања. Многе режимски настројене новине ликовале су због краха тоталитаризма, иако су у редакцијама сједили исти новинари, који су се сада експресно прилагодили промјенама. Дјед је окупио неколико снажних момака, који су убрзо сазнали гдје је фашиста Тикван, и на дан 2. августа, тачно двадесет једну годину након што је присиљен да попије рицинус, отишли су да поравнају 
рачуне, зграбили силеџију, запушили му нос и нагутали га опасне материје. По повратку кући, дјед је сијао од задовољства, дочекавши свој правични преокрет. Из дубина Јамбовог сјећања Амалија је побудила причу коју му је дјед причао више пута, па су се неизбрисани детаљи бочице, стрипова и личне среће због вишеструке катарзе вратили у памћење и ту заувијек остали. Битан детаљ језичке археологије повезује више нити у Јамбовом етичко-грађанском развитку:

„А ви, господичићу Јамбо, као да вас сада гледам, пљескали сте рукама и викали алал вера деда бољи си од гудона.“ „Од гудона? Шта је то гудон?“

„Откуд ја знам? Али тако сте узвикивали, очију ми, као да вас сада чујем.“

Није то био гудон, него Гордон. ја сам дедин чин поистоветио са побуном Флаша Гордона против Минга, тиранина са планете Монго. (Еко 2004: 291)

У вези са овим збацивањем, јунак схвата и градацију у називању партизана - од избјегавања регрутације преко побуњеника до партизана (у Солари су се отворено појављивали од 1944. године). Са Радио Лондона стижу поруке да је Дуче упропастио Италију, али и шифроване поруке, пошто је досад Јамбу јасно да не може безрезервно вјеровати никоме од зараћених. Помало оптерећен погибијом друга Грањоле током спасавања Козака, Јамбо се присјећа и поново проживљава бол с краја рата, усред бујног живота у нетом задобијеној слободи: град је у априлу 1945. године окупан ноћним свјетлима, преплављен жамором на улици, биоскопи раде и под ведрим небом; ратови се сада воде на холивудски начин у филмовима Џима Кегнија, а на киосцима се види нова верзија историје, Хирошима и 
концентрациони логори, док се дјеца смију геговима Абота и Костела, стижу Бинг Крозби и Боб Хоуп, „а сви, уосталом, као и 1944, мисле да је живот леп“ (Еко 2004: 407).

\section{Извори и литература}

Abbott, Arthur. "Primers for Fascists and Democrats". The Elementary School Journal, 43.5 (1943): 282-289. Print.

Еко, Умберто. Тајансиивени йламен краљиие Лоане. Превели Мирела Радосављевић и Александар Леви. Београд: Народна књига, 2004. Штампано.

Horn, David G. "Constructing the Sterile City: Pronatalism and Social Sciences in Interwar Italy". American Ethnologist, 18. 3 (1991): 581-601. Print.

Marino, John, et al. "Italy - The Fascist Era". Encyclopaedia Britannica, 2019. Web. 14.02.2019.

Nelis, Jan. "Constructing Fascist Identity: Benito Mussolini and the Myth of 'Romanità'”. The Classical World, 100. 4 (2007): 391-415. Print.

Wolff, Richard J. "Catholicism, Fascism and Italian Education from the Riforma Gentile to the Carta Della Scuola 19221939". History of Education Quarterly, 20.1 (1980): 3-26. Print. 
Sergej Macura

\section{RECONSTRUCTING HISTORICAL EVENTS THROUGH CHILDREN'S READING: THE MYSTERIOUS FLAME OF QUEEN LOANA}

The main character of Umberto Eco's novel, Giambattista Bodoni remembers his own life after a stroke and starts off with the earliest reading experiences in order to overcome his amnesia. He publicly absorbed Fascist ideology while at school without knowing enough about the fundamentals of that system, and now he is investigating what attitude towards Fascism he had in his childhood. Fifty years later, Bodoni realises the burden that trauma and repression left on his family members, especially on his grandfather, whose resistance and revenge on Fascist oppressioncan be considered both the familial and generational experience of an entire nation. The found text consists of primers, propaganda materials and a huge number of comics.

Key words: reconstruction, Fascism, totalitarianism, comics, propaganda, semantic memory, autobiographic memory, Umberto Eco, Benito Mussolini. 